\title{
Education, Empowerment and Access to All - Public Legal Education and Massive Open Online Courses at the Law Society of Ireland
}

\author{
Dr. Freda Grealy, \\ Steve Collender, \\ John Lunney, \\ Rory O'Boyle ${ }^{1}$
}

\begin{abstract}
Since 2014, the Diploma Centre at the Law Society of Ireland ('the Society') has implemented a programme of MOOCs; 'Massive Open Online Courses' in key areas of practice. This article outlines the provision of Public Legal Education at the Society and how MOOCs align with the mission to widen access to legal education and the legal profession. Of interest to others who may be developing MOOCs, we discuss the instructional design process and feedback from MOOC participants. MOOCs are very much on trend and have received a mixed reception but, subject to course design, they can provide substantial educational benefit and operate as an effective means to widen access to education.
\end{abstract}

\footnotetext{
${ }^{1}$ Head of Diploma Centre, Solicitor, Law Society of Ireland; Multimedia Coordinator, Diploma Centre; Solicitor, Course Manager; Solicitor, Course Manager, Law Society of Ireland.
} 


\section{Introduction}

The annual Massive Open Online Course (MOOC) presented by the Diploma Centre ${ }^{2}$ embraces the Law Society of Ireland ('the Society')'s public interest mission to provide access to legal education and the legal profession. The Society's strategic objectives ${ }^{3}$ were recently updated to specifically reference "our tradition of engaged citizenship and civic responsibility by promoting legal awareness and encouraging social diversity within the profession..." To date, the Diploma Centre's MOOCs have attracted in excess of 12,000 registrants from over 70 countries. The core aim for the MOOCs is to design and deliver a course that fits with the Law Society's mission to widen access to legal education, i.e. a course that is easily accessible and free for everyone.

The core structure of our MOOCs has stayed broadly similar since they first launched in 2014. Our approach is to deliver an education programme over five weeks consisting of a weekly module release. The main learning resources consist of the weekly release of a set of video recordings on the weekly topic supplemented by further reading and discussion forum threads. From an educational design point of view, the modules are structured to encourage peer-to-peer learning, fostering online engagement on the course forum as a means to enhancing the learning experience and

\footnotetext{
2 The Diploma Centre, as part of the Education Department at the Law Society of Ireland, has provided continuing professional legal education for over twenty years, offering a diverse range of postgraduate courses which are available both onsite and online. These courses are open to solicitors, trainees, and barristers, with a number of courses welcoming suitably qualified non-legal professionals.

${ }^{3}$ Awaiting publication, Law Society of Ireland.
} 
encourage the development of a community of practice. Course delivery emphasises a hands-on practical learning approach, with clear learning outcomes outlined for each module and a comprehensive video introduction curated by the team at the outset of each week. Later in the week, there is an opportunity for real time engagement with an expert through an online Question \&Answer session. Each weekly module is then bookended by a self-assessed multiple-choice quiz (MCQ).

In terms of the demographic profile of our participants over 50 per cent are educated to postgraduate level or above, with a further 32 per cent holding undergraduate degrees. Students from a legal background accounted for 37 per cent of the total participants of MOOC courses between 2016 and 2018. Although participants are predominantly based in Ireland, the percentage of international students has increased each year to a record high of 13 per cent in $2018^{4}$.

MOOCs provide individuals and businesses with a greater understanding of the law, and also provide educational value while highlighting a commitment to embrace technology and provide public legal education online. This article explores the positive opportunity MOOCs provide for a professional representative and educational body such as the Law Society of Ireland to open up legal education and to welcome the public; thus increasing overall knowledge and understanding of the law.

\footnotetext{
${ }^{4}$ Appendix A: MOOC demographic profile 2016 - 2018:
} 


\section{What is Public Legal Education?}

Public Legal Education (PLE) covers a wide range of activities aimed at empowering participants and increasing their confidence and capability to deal with law-related issues $^{5}$. PLE is provided worldwide in many different guises and by a myriad of organisations, from state and private organisations to volunteer entities and universities. In many countries, such as the UK, Canada, and the USA, PLE is closely aligned to access to justice and encouraging the public to increase their confidence and empower them to deal with law-related issues. In this process, the increasing legal literacy levels contribute to enhancing access to justice more generally ${ }^{6}$.

The breadth of PLE initiatives globally and the various modalities employed make it somewhat amorphous and difficult to define. One important factor to emphasise particularly, bearing in mind that the Society is a member organisation for solicitors, is that PLE is fundamentally about education and information and not the provision of legal advice7. A working definition of PLE was used by the authors of the report of the PLEAS Taskforce ${ }^{8}$;

\footnotetext{
${ }^{5}$ Solicitor General's Committee on Public Legal Education, 'A Ten Year Vision for Public Legal Education' (LawWorks, 31 October 2018), <https://www.lawworks.org.uk/sites/default/files/files/10YearVisionForPLE-web.pdf>

${ }^{6}$ Richard Grimes, 'Evaluating legal literacy programmes - aims, challenges, models and a call to action' (2018) 2(1) International Journal of Public Legal Education 28.

${ }^{7}$ For a fuller discussion of the distinction between legal advice, legal information and legal self-help see: Ashley Falk, Michelle Korpan \& Noah Wernikowski, 'Legal Information, Legal Advice \& Access to Justice' (University of Saskatchewan Dean's Forum, 1 March 2017) <https://law.usask.ca/documents/research/deans-forum/Paper\%201\%20\%20Legal\%20Information,\%20Legal\%20Advice\%20Access\%20to\%20Justice\%20.pdf>

8 Public Legal Education and Support (PLEAS), 'Developing capable citizens: the role of public legal education' (Law for Life, July 2007) <https://lawforlife.org.uk/wp-content/uploads/2013/05/pleas-task-force-report-14.pdf> accessed 12 December 2018
} 
PLE provides people with awareness, knowledge and understanding of rights and legal issues, together with the confidence and skills they need to deal with disputes and gain access to justice. Equally important, it helps people recognise when they may need support, what sort of advice is available, and how to go about getting it. PLE has a further key role in helping citizens to better understand everyday life issues, making better decisions and anticipating and avoiding problems.

As the Law Society of Canada outlines, some organisations call this work "community legal education (CLE), law-related education (LRE), legal literacy, legal capability, or legal empowerment." They observe that "[the] terms 'education' and 'information' are also used interchangeably!" 9 ; however Grimes ${ }^{10}$ differentiates between these two headings and notes that despite a wide range of activities, PLE can generally be grouped into two categories;

i. The provision of information, and

ii. More formal education interface such as one off presentations or structured courses and programmes.

Furthermore, terms such as 'Street Law' to connote community legal education are also prominent forms of PLE, as are seminars and clinics in the community. Many law

\footnotetext{
${ }^{9}$ Lois Gander, 'Defining PLE' (Public Legal Education Canada, 2015) <http://www.plecanada.org/what-is-ple/defining-ple> accessed 12 December 2018

${ }^{10}$ Richard Grimes, 'Evaluating legal literacy programmes - aims, challenges, models and a call to action' (2018) 2(1) International Journal of Public Legal Education 28
} 
students are involved in these worthy initiatives offering experiential learning opportunities, which teach valuable skills and develop them as lawyers.

Significant supports exist for PLE initiatives from Bar Associations, Regulators, and Law Societies but unlike the Law Society of Ireland, few, if any, of these organisations actually fund and offer these initiatives directly ${ }^{11}$. The American Bar Association in the USA has a Public Education Division, that offers law-related resources and programs to educators, students, journalists, legal professionals, opinion leaders, and the public to promote understanding of law and its vital role in our society. ${ }^{12}$ The Canadian Bar Association is very forthright in its support of PLE, as this note from its website attests;

In every province in Canada, organizations have been set up to provide essential legal information to members of the public. These non-profit and non-governmental groups believe that Canadians cannot fully exercise their rights unless they know about and understand the laws and the justice system that affects them. Providing easy access to information on the law is fundamental to a fair justice system. ${ }^{13}$

The Solicitors Regulatory Association in the UK is likewise supportive and has published a number of resources and reports ${ }^{14}$. Most notable in the UK is the 2018

\footnotetext{
${ }^{11}$ Encouraged by the response to MOOCs at the Law Society of Ireland, the Law Society of Scotland ran their first MOOC in 2017. They collaborated with a large local firm who specialised in shipping law and indicate that they plan to launch another MOOC. See further: <http://www.journalonline.co.uk/Magazine/62-12/1024127.aspx\#.XDyuSc_7Rok> accessed 12 January 2019

12 https://www.americanbar.org/groups/public education/)

13 The Canadian Bar Association, 'Public legal education and information in Canada' (The Canadian Bar Association, 2018) $<$ http://www.cba.org/For-The-Public/Public-Legal-Education-and-Information-in-Canada> accessed 21 December 2018 ${ }^{14}$ The Law Society, 'Public legal education' (The Law Society, 2018) <https://www.lawsociety.org.uk/supportservices/public-legal-education> accessed 21 December 2018
} 
announcement by Solicitor General Robert Buckland QC MP of a ten-year vision for PLE which listed seven goals. ${ }^{15}$

\section{Public Legal Education at the Law Society of Ireland}

The Law Society of Ireland is the educational, representative, and regulatory body for the approximate 18,000 members of the solicitors profession in Ireland. ${ }^{16}$ The provision of legal information to the public has historically been provided by the Law Society of Ireland in tandem with its three pillar functions. Currently the Society's website $^{17}$ is the main repository for information for the public and has its own dedicated section for this purpose. While the Society cannot provide legal advice, there is a helpful 'Legal Guides' section where the public can access information on a range of legal areas such as employment law, dispute resolution, and legal aid.

In 2013 , the Society moved beyond merely providing information to the public and offered for the first time a more formal PLE course designed for the community. This was offered through a Street Law programme developed by the Diploma Centre, where trainee solicitors were placed in local schools to teach transition year students ${ }^{18}$ about law. At the heart of Street Law is a social justice ethos promoted through the use of learner-centred teaching methodologies and pedagogy. Initially, the main objective for our PLE project was simply to provide law-related education in the

\footnotetext{
${ }^{15}$ Robert Buckland QC MP \& Attorney General's Office, 'Our vision for legal education' (Government UK, 31 October 2018) $<$ https://www.gov.uk/government/news/our-vision-for-legal-education> accessed 31 October 2018

${ }^{16}$ Approximately 11,000 of our 18,000 members hold practicing certificates

17 https://www.lawsociety.ie/Public/

${ }^{18}$ In Ireland, the transition year (TY) is a one-year programme offered between the Junior and Senior cycle at secondary school - see <https://www.education.ie/en/Schools-Colleges/Information/Curriculum-and-Syllabus/Transition-Year-/>
} 
community and to encourage and support an ethos of public service amongst trainee solicitors. We also recognised the potential educational benefits to trainee and practicing solicitors who delivered PLE.

Our list of programmes has also expanded in addition to our Street Law schools programme;

- Street Law Prison ${ }^{19}$, collaborating with organisations such as Solas ${ }^{20}$ and working with detainees in Wheatfield, Mountjoy Prison, Oberstown and the Dochas Centre.

- Solicitors of the Future ${ }^{21}$, an innovative work experience programme for school students which provides students with an introduction to the solicitor's profession

- Certificate in Public Legal Education ${ }^{22}$, which aims to develop the skills of solicitors to run an effective PLE programme in their own communities

- Working with community service organisations such as Public Interest Law Alliance (PILA) and Future Voices ${ }^{23}$ to assist a group of youths in making a submission to the Law Reform Commission on proposed cyber-bullying legislation.

\footnotetext{
${ }^{19}$ https://www.lawsociety.ie/Public/Public-Legal-Education/streetlaw-prison/

${ }^{20}$ http://solas.ie/

${ }^{21}$ https://www.lawsociety.ie/futuresolicitors

22 https://www.lawsociety.ie/Public/Public-Legal-Education/certificate-in-public-legal-education/

23 http://futurevoices.ie/
} 
In addition, our Street Law Orientation model run in collaboration with Professor Richard Roe and fellows of the Georgetown Street Law clinic ${ }^{24}$ has become a launch pad for other educational institutions to develop their own PLE Street Law programmes. Each year, we facilitate institutions interested in launching their own programmes in attending at this weekend training, which has supported new Street Law programmes at Law Society of Scotland, Letterkenny IT, Open University, Middlesex University, University of Birmingham, National University of Ireland, Galway and the University of Limerick.

\section{How MOOCs fit within PLE}

MOOCs have developed as a stream of the open education movement generally and feature common traits including being open, participatory, distributed, and supporting lifelong learning. Given that they are open to all, MOOCs have contributed to a democratisation of education; they have the advantage to providers of scalability and extending reach globally. Online learning can still be regarded as problematic and the quality of learning offered may be suspect if the proper learning supports are not in place ${ }^{25}$. More recent research advises educators to "harness the enormous

\footnotetext{
${ }^{24}$ Sean Arthurs, Melinda Cooperman, Jessica Gallagher, Freda Grealy, John Lunney, Rob Marrs, \& Richard Roe, 'From Zero to 60: Building Belief, Capacity and Community in Street Law Instructors in One Weekend' (2017) 24(2) International Journal of Clinical Legal Education, 118-241

${ }^{25}$ Five factors found within landmark study of three MOOCs: (1) problem-centric learning with clear exposition, (2) instructor accessibility and passion, (3) active learning, (4) peer interaction, and (5) using helpful course resources. Hew, K. F. (2014) 'Promoting engagement in online courses: What strategies can we learn from three highly rated MOOCs', British Journal of Education Technology, 47(2), pp. 320-341. doi: 10.1111/bjet.12235
} 
opportunities that MOOCs might afford for providing access to knowledge and education, whilst equally addressing problematic issues like high dropout rates and sustainable cost models" 26 .

Buoyed by the enthusiastic reception for Street Law and mindful of the public's increased demand and interest in understanding the law and the solicitor profession, we piloted the inaugural MOOC in 2014 in 'Aviation Leasing and Finance', an industry which has a significant presence in the jurisdiction.

The Society as an institution has always had a strong sense of corporate social responsibility (CSR) represented by a vision for responsible and sustainable business practice through the adoption and implementation of best practice in $\operatorname{CSR}^{27}$. The Society strives, in partnership with members, trainee solicitors, and employees, to work in a responsible and ethical way, to lead by example, to be a champion of CSR among the profession, and to continuously improve activities and processes.

The PLE initiatives have significant institutional support amongst staff and management. The National Plan on CSR in Ireland 2017-202028, also identifies "Community" as one of its four core dimensions (workplace, marketplace, environment and community). In relation to this core pillar of community, the PLE

\footnotetext{
${ }^{26}$ Olaf Zawacki-Richter, Aras Bozkurt, Uthman Alturki \& Ahmed Aldraiweesh, 'What Research Says About MOOCS - An Explorative Content Analysis' (2018) 19(1) International Review of Research in Open and Distributed Learning 252. 10.19173/irrodl.v19i1.3356

27 Law Society of Ireland, 'Corporate Social Responsibility Statement' (Law Society of Ireland, 2018)

${ }^{28}$ Department of Enterprise and Innovation, 'Towards Responsible Business, Irelands National Plan on Corporate Social Responsibility 2017 -2020' <https://dbei.gov.ie/en/Publications/Publication-files/Towards-Responsible-BusinessIreland\%E2\%80\%99s-National-Plan-CSR-2017-2020.pdf> accessed 21 February 2019
} 
project aligns with the dual objectives of provision and promotion of legal information and community engagement. We are mindful of the privilege of our position and keen to instil in future generations of the profession the positive contribution that they can make to the community with their legal training. We are keen to support the public interest in encouraging wider access to legal education and to the legal profession, and our PLE programmes deliver on both counts. Significantly the most recent version of the Law Society of Ireland Future Strategy Statement includes a goal that the Society specifically promotes '[E]ngaged citizenship and civic responsibility by promoting legal awareness'. The Society has identified the potential of MOOCs to align with this strategy by raising legal literacy levels and engaging the public in free legal education $^{29}$.

The success of our MOOC series is reflected in the upward trajectory in participant numbers - from a student count of 900 on the inaugural offering in 2014 to over 3,200 in 2017, and a cumulative total of 10,000 students over the five year period since 2014 . The goal of MOOCs at the Society was to widen the provision of public legal education and in the process extend our reach by introducing our educational offerings on a larger scale to potential Diploma Centre students both nationally and internationally. This digital initiative opened up the Law Society to a large audience of legal and nonlegal professionals alike and demonstrated the commitment of the organisation to the public interest and increasing access to justice and an understanding of the law. The

\footnotetext{
${ }^{29}$ Approximately 11,000 of our 18,000 members hold practicing certificates. Confusing use of certificates, diplomas.
} 
themes of the annual MOOCs at the Society are aligned to topical subject matter areas likely to have widespread appeal for lawyers and non-lawyers alike and cover areas of practice including technology law, data protection, finance, employment law and media, arts and entertainment law. It is made clear that the subject of our MOOCs is the law as it applies in Ireland, but where appropriate with EU and international dimensions fully explored. The importance of the topic and its applicability across learning domains and countries creates a unique space for lawyer and non-lawyer engagement (as peers) and aligns with the Society's mission to widen access to legal education and to the legal profession.

The MOOC has consistently appealed to students outside of the legal sphere. MOOCs are easily accessible and the ability for students to direct their own learning in a selfpaced manner suits the schedule of the busy professional or full-time student. In 2018, 50 per cent of students identified their highest education level attained as within the non-legal sphere. Similarly, 41 percent of students on the 2017 Employment Law MOOC were from non-legal backgrounds. 


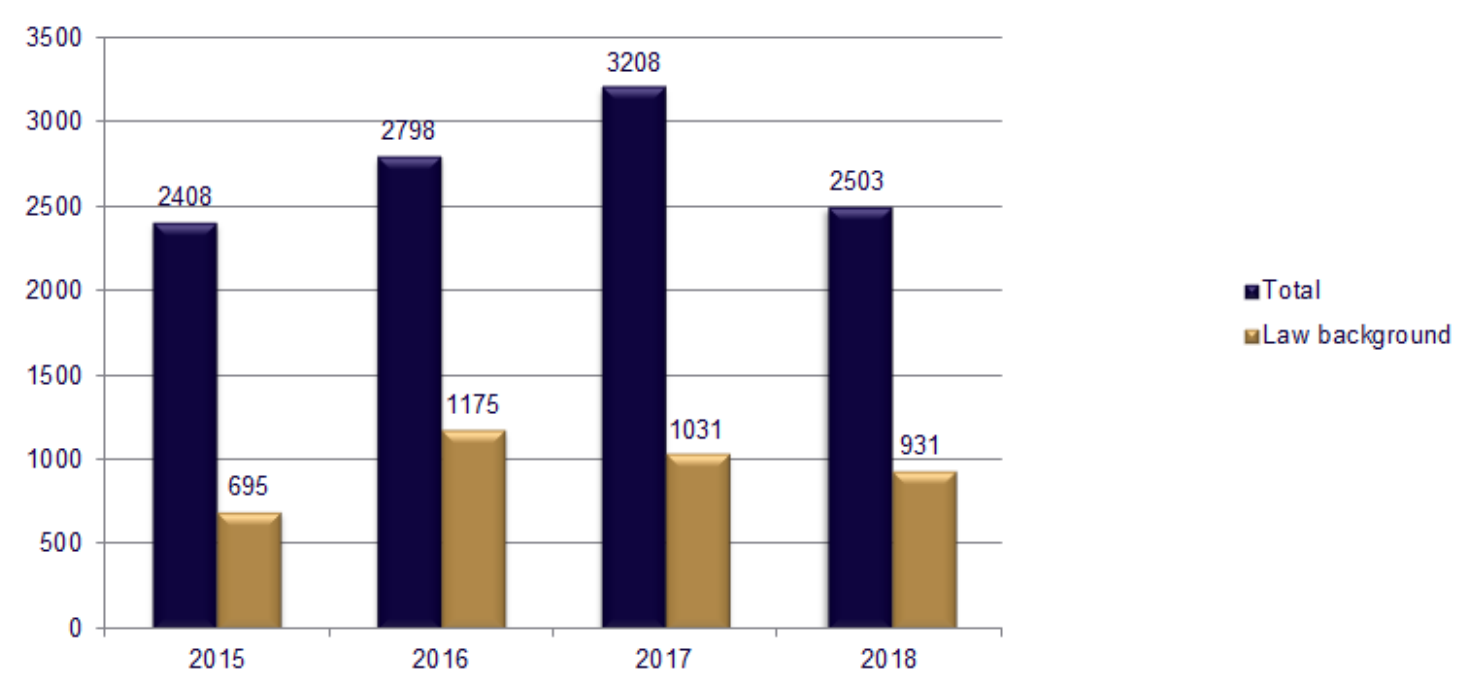

Figure 2: Student background by year (2015 - 2018)

The intrinsic role of the MOOC as a knowledge provider has also been noted in our survey responses. 93 per cent of students on the final evaluation survey of the 2018 Sports Law MOOC noted that their primary motivating factor for undertaking the course was to enhance their knowledge of the topic. Attending the course was purely to gain knowledge, so accreditation was not their primary interest. The Law Society recognises that imparting legal knowledge is fundamentally a public good, and the MOOC is utilised as an effective resource to impart this knowledge for free. However, the purpose of our approach is to go beyond merely providing information and stating what the law is in a particular area, and to provide examples of law in action and how the law can be applied. A deeper understanding is encouraged by exposing students to the law in applied situations and affording an opportunity to problematise and deepen the learning, turning the information into knowledge, and maximising the educational benefit. 
Our 2017 MOOC, for example, explored current employment law issues relevant to a variety of topics concerning law, business, and human resources in the digital age. These included social media in the workplace; equality law in Ireland; anatomy of an unfair dismissal; dispute resolution mechanisms; industrial relations in Ireland; and employment consequences for Ireland post-Brexit. We also drew on speakers from a myriad of other professions outside of the legal sphere, in keeping with our ethos of openness and collaboration with other sectors. By taking a multifaceted approach which emphasises different modalities, the MOOCs have been tailored to provide a meaningful learning experience that goes beyond the mere descriptive or the provision of information and are of educational benefit.

Development of the MOOC programme has also allowed us to expand outwards to public education initiatives in other jurisdictions. In 2017, the Diploma Centre was part of an international group awarded a grant by the European Commission for the provision of a training course on the EU Victims' Impact Directive using our MOOC infrastructure. The course utilised the same format as the MOOC and attracted interest from the Gardaín ${ }^{30}$ Victims Support Groups, civil liberty advocates, and related professions in Ireland and abroad.

In summary, the primary objectives and motivators for the Law Society of Ireland in the design and delivery of MOOCs is to provide a course that:

${ }^{30}$ Gardaí is the name for the Irish Policing Authority. 
1. Aligns with the public interest and corporate social responsibility ethos of the Society to serve the community

2. Fits within the Society mission to widen access to legal education and to the profession

3. Provides individuals and businesses with a greater understanding of the law

4. Enhances the positive reputation of the profession and the professional body of the Society

5. Highlights the Society's commitment to embrace technology and online learning and upskills team members

6. Creates a positive online experience for students to incentivise uptake of further diploma offerings

\section{Designing a MOOC with a PLE focus}

One of the key challenges in distance education is preventing student drop off. Research from 2013 indicates that typically fewer than 7 per cent of students complete MOOC programs ${ }^{31}$. HarvardX and MITx have gone further, reporting in January 2017 that only 5.5 per cent of people who enrol in one of their open online courses earn a certificate $^{32}$. Many students undertake MOOCs as a means of adding to their

\footnotetext{
31 Times Higher Education, 'MOOC completion rates “below 7\%”'(Times Higher Education, 2013)

32 Massachusetts Institute of Technology, 'Study of MOOCs offers insights into online learner engagement and behavior', (MIT Office of Digital Learning, 2017) <https://blog.edx.org/study-moocs-offers-insights-online-learner-engagementbehavior $>$ accessed 29 August 2018
} 
professional knowledge and skills and future employability. They are keen to receive an official document confirming their successful completion of the course, which is why the certificate is provided as an optional purchase under a 'freemium' model common to other MOOC providers ${ }^{33}$.

Our MOOCs have consistently bettered these dropout rates, with completion levels of 12.6 per cent and 11 per cent most recently on the 2017 and 2018 courses, respectively. The courses follow best practice by implementing a variety of learner-centric activities such as videos, discussion forums, learning resources, weekly quizzes, and social media tasks. The experience is intended to engage the learner with tasks and activities provided so that participants have a chance to apply the learning objectives each week and are incentivised to earn a weekly badge for successful completion of these tasks and for posting to the discussion forum. The practices employed on MOOC offerings by the Diploma Centre were a huge driver in unlocking the potential for development of online learning on our standard suite of courses.

We have utilised the ADDIE (analysis, design, development, implementation, evaluation $)^{34}$ model of instructional design to structure the development of these MOOCs. In addition to the sequential model of ADDIE as the principle development framework, we have retained the flexibility to adopt and adapt ideas from other

\footnotetext{
${ }^{33}$ Porter, S. (2015) 'The economics of MOOCs: A sustainable future?', The Bottom Line, 28(1/2), pp. 52-62. doi: 10.1108/BL-12-2014-0035

${ }^{34}$ Rebecca A. Croxton and Anthony S. Chow, 'Using Addie and systems thinking as the framework for developing a MOOC: a case study' (2015) 16(4) Quarterly Review of Distance Education 83; Norazah Nordin, Mohamed Amin Embi, \& Helmi Norman, 'Towards Envisioning the Future of Learning in Malaysia: Development of a Malaysia MOOC: Based on the Iterative ADDIE Instructional Design Framework' in Envisioning the Future of Online Learning (Springer 2016) 269-279
} 
instructional design models. The key outcome of our analysis phase, as noted previously, was the fundamental importance of the topic choice. From a public legal education perspective, our goal was to create a unique online space where lawyer and non-lawyer could engage as peers. This necessity creates the requirement that the selected area of law has applicability across learning domains and countries.

The MOOC was hosted on Moodle, our existing learning management system (LMS), rather than investment in an external platform as other MOOC providers such as FutureLearn and Coursera. We recognised that by creating our own bespoke learning environment for the MOOC, we placed ourselves in a position to make continuous improvements to our LMS, which in turn would impact positively on the online learning environment for our standard diploma and certificate offerings. Furthermore, this mode of delivery was a means of achieving cost effectiveness in offering a free course to the public and provides continuity to our other offerings.

At the design stage, our approach was to remove obstacles and to ensure the course was easily accessible via an intuitive course interface design. A common criticism of MOOCs is that they are "well packaged; [but] their instructional design quality is low"35. Feedback from previous MOOCs and our profile of online learners was incorporated into the design stage when working with our e-learning solutions partner Enovation ${ }^{36}$. This helped us to orient the learning environment around user

\footnotetext{
35 Anoush Margaryan, Manuela Bianco \& Allison Littlejohn, 'Instructional quality of massive open online courses (MOOCs)' (2015) 80 Computers \& Education 77. doi: 10.1016/j.compedu.2014.08.005

${ }^{36}$ https://enovation.ie/
} 
experience; developing an interface that would be user-friendly, engaging and appealing to users of all technical levels. Factors to consider were:

- High dropout rates;

- Risk of student isolation;

- The need to cater for mixed profile of participants; and

- Varying student motivations for taking part.

Best practice suggests prioritising user experience at the core of course design decisions. Our standard online system has been adapted to the needs of our typical student profile, the 'busy, time poor professional' who requires a system which enables them to learn on-the-go. However, our MOOCs have attracted interested persons of all ages, from younger students in their twenties to retirees in their seventies, and therefore appealing to students across the age spectrum and from a broad range of demographics was a key concern.

A welcoming, friendly tone is adopted in course communications with guidance and support provided by the Diploma team, who personalise the experience and act as essential points of contact to bridge the gap between students and the weekly presenters. The provision of a weekly opportunity for real time engagement with subject matter experts aims to overcome the criticism often levelled at MOOCs of lack of instructor accessibility ${ }^{37}$. A low level of instructor accessibility is likely to exacerbate

\footnotetext{
37 Joe Warren, Scott Rixner, John Greiner \& Stephen Wong, 'Facilitating human interaction in an online programming course' in Proc. SIGCSE 2014 (ACM Press 2014) $665-670$
} 
student feelings of isolation, whereas a high level of accessibility is shown to encourage student engagement ${ }^{38}$. Since the 2017 MOOC, we have incorporated a weekly lunchtime 'question \& answer' session filmed on location at the offices of legal experts contributing to the course, whereby students could tune in and engage in discussion with the experts via a live video chat.

At development stage each year, the creation of video recordings is the dominant aspect in our considerations. From a practical perspective, the work of $\mathrm{Guo}^{\mathrm{a}} \mathrm{al}^{39}$ on the effect of video production on student engagement has proved a significant resource. The authors of this empirical study, which was ground-breaking in terms of its scale (data measured from 6.9 million video-watching sessions across four MOOC courses), produced a set of video production recommendations ${ }^{40}$ that now provide educators with a template of best practice, which we have utilised as a framework for developing the video content on our MOOCs.

Readers may also be interested to learn that following on from the goal of the MOOC to provide public legal education and widen access to legal information, expert practitioners have been willing to contribute on a pro bono basis to the course. During pre-production, we take the time to discuss with our contributors how best to set up

\footnotetext{
38 Khe Foon Hew, 'Promoting engagement in online courses: What strategies can we learn from three highly rated MOOCs' (2014) 47(2) British Journal of Education Technology 320-341. doi: 10.1111/bjet.12235

39 Philip J. Guo, Juho Kim \& Rob Rubin, 'How video production affects student engagement: An empirical study of MOOC videos' in Proceedings Of The First ACM Conference On Learning@Scale Conference 2014 (ACM Press 2014) 41-50 Juho Kim, Philip J Guo, Daniel T Seaton, Piotr Mitros, Krzysztof Z Gajos, Robert C Miller, 'Understanding in - video dropouts and interaction peaks in online lecture videos' in Proceedings Of The First ACM Conference On Learning@Scale Conference 2014 (ACM Press 2014) 31-40

40 Ibid, supra n. 16, p 42.
} 
their presentations and suggest methods for effectively engaging students, before commencing work with a video production team to record and edit the presentations. Different modalities are used to impart lecture content, e.g. some videos take the form of an informative straight-to-camera featurette with a solo participant, while others involve multiple interviewees talking together in a relaxed, informal style.

In order to successfully complete the course, students are required to have actively engaged with the discussion forum by posting at least three times to any of the forums over the duration of the course. Integrating the discussion forum requirement with the assessment is an effective means to both increase the volume of conversation online and the quality of comments offered by participating students. As Nagel and Kotzé $^{41}$ have found, "[w]hen students engage in online activities and take responsibility for the quality of interaction, they can have a superior learning experience" ${ }^{\prime \prime 2}$.

This space is also unique in creating the opportunity for meaningful engagement between the public and legal experts as peers. The use of discussion forums on online courses has also been proven to correlate with higher student retention rates and higher grades upon completion ${ }^{43}$. Online socialisation has become an important component in the success of our MOOCs, with participants encouraged to interact on

\footnotetext{
${ }^{41}$ Lynette Nagel \& Theuns G. Kotzé, 'Supersizing e-learning: What a Col survey reveals about teaching presence in a large online class' (2009) 13(1) Internet and Higher Education. doi:10.1016/j.iheduc.2009.12.001

$42 \mathrm{Ibid}, \mathrm{p} .50$

${ }^{43}$ Derrick Coatzee, Armando Fox, Marti A. Hearst, \& Björn Hartmann, 'Should your MOOC forum use a reputation system?' in Proc. CSCW 2014 ACM (2014) $1176-1187$
} 
the discussion forums with fellow students. In the evaluation survey for the 2018 course, 91 per cent of students rated the discussion forum favourably in their assessment of the course. A dedicated thread was also available for students to post any technical queries and a member of the course team was assigned to monitor and respond promptly to such issues.

Our evaluations suggest that when designed and managed properly, MOOCS have the capability to offer effective learning through practical student engagement. Many students noted in the survey responses that they come back for the MOOC year on year. For some, it started as their first foray into legal education, and the provision of an annual free learning resource has enriched their understanding of the law, as well as encouraged them to partake in further legal education and register for a Diploma or Certificate course.

We contend that our MOOC experience showcases the potential of online courses as a means of developing public legal education initiatives. While our MOOCs have been led by seasoned professionals, we propose that there may be an opportunity for educational institutions to develop programmes in collaboration with law students. As the literature now looks at SPOCS (small private online course) ${ }^{44}$ in addition to MOOCs, we pose the question of whether involving law students in the provision of a bespoke online law courses could potentially benefit the law students in acquiring

\footnotetext{
44 Armando Fox, "From MOOCs to SPOCs". Commun. ACM, 56(12) ( 2013 ) pp.38-40. Kaplan, Andreas M., and Michael Haenlein. "Higher education and the digital revolution: About MOOCs, SPOCs, social media, and the Cookie Monster." Business Horizons 59.4 (2016): 441-450.
} 
the type of transferable skills required by law graduates? Involving law students in the development and delivery of such courses could potentially provide them with a framework to gain inter disciplinary experience, project management skills and the ability to understand and employ technology skills which have all been identified as essential for the future practice of law ${ }^{45}$. This would be an interesting area for future research.

\section{Conclusion}

The overall PLE programmes have a long-term impact in shaping and empowering the education, skills and values of the public and those of the profession who deliver the programmes. Our provision of MOOCs plays a part in this, equipping professionals in the sector with improved legal capability and the ability to make better choices concerning the legal issues they face daily. The Solicitor General's Committee on PLE ${ }^{46}$ in the UK identifies the goal of scaling PLE through delivery by the legal community. Our experience is testament to the positive impact that this can have on a legal education institution and on legal professionals. The MOOC series has generally portrayed the legal community in a positive fashion and broken down barriers between the public and the profession through the creation of a free space for interaction and engagement as peers.

\footnotetext{
45 Michael. Legg, "New Skills for New Lawyers: Responding to Technology and Practice Developments." (2018).

${ }^{46}$ Robert Buckland QC MP \& Attorney General's Office, 'Our vision for legal education' (Government UK, 31 October 2018) https://www.gov.uk/government/news/our-vision-for-legal-education> accessed 31 October 2018
} 
The profile of the Society as a flagship for online learning and public legal education has also been enhanced; as evidenced by increased student numbers on our diploma courses and the uptake from international learners. Prior to 2014, there were no students outside of Ireland registered on certificate and diploma courses, whereas 148 students based outside of Ireland have undertaken a diploma or certificate course since the first MOOC launch. Technically, we have improved the user experience by enhancing our online tools and producing higher quality learning content through more efficient use of the team's resources, leading to a more energised team and furthering possibilities for subsequent courses.

Our ultimate goal was to increase the provision of public legal education on a wider scale and introduce students to our enhanced online learning system. As part of our findings, the experience affirmed a strong interest and uptake internationally for online learning. We have seen the benefits of peer interaction on an unprecedented scale, and gained experience in producing effective and engaging learning content at low cost. Subject to course design, this can provide substantial educational benefit and operate as an effective means to widen access, market courses through 'testers', and promote a providers brand for high quality online courses. This digital initiative has opened up the Law Society to a large audience of legal and non-legal professionals alike and demonstrated the commitment of the organisation to public interest and increasing access to justice and an understanding of the law. 
Appendix A: MOOC demographic profile 2016 - 2018:

\begin{tabular}{|l|cc|}
\hline & \multicolumn{2}{|c|}{ Gender } \\
\hline & Male & Female \\
\hline 2016 Total Registered \% & $64 \%$ & $36 \%$ \\
\hline 2016 Total Completed \% & $51 \%$ & $47 \%$ \\
\hline 2017 Total Registered \% & $29 \%$ & $71 \%$ \\
\hline 2017 Total Completed \% & $37 \%$ & $63 \%$ \\
\hline 2018 Total Registered \% & $55 \%$ & $45 \%$ \\
\hline 2018 Total Completed \% & $50 \%$ & $50 \%$ \\
\hline
\end{tabular}

\begin{tabular}{|l|rrrrrr|}
\hline & \multicolumn{7}{|c|}{ Age } \\
\hline & $20-29$ & $30-39$ & $40-49$ & $50-59$ & $60-69$ & \multicolumn{1}{l|}{ Over 70 } \\
\hline 2016 Total Registered \% & $23 \%$ & $38 \%$ & $25 \%$ & $11 \%$ & $3 \%$ & $0 \%$ \\
\hline 2016 Total Completed \% & $22 \%$ & $39 \%$ & $22 \%$ & $11 \%$ & $6 \%$ & $0 \%$ \\
\hline 2017 Total Registered \% & $24 \%$ & $37 \%$ & $25 \%$ & $12 \%$ & $2 \%$ & \\
\hline 2017 Total Completed \% & $24 \%$ & $39 \%$ & $23 \%$ & $12 \%$ & $2 \%$ & \\
\hline 2018 Total Registered \% & $25 \%$ & $33 \%$ & $25 \%$ & $12 \%$ & $3 \%$ & $0 \%$ \\
\hline 2018 Total Completed \% & $24 \%$ & $29 \%$ & $23 \%$ & $14 \%$ & $3 \%$ & \\
\hline
\end{tabular}

\begin{tabular}{|l|rr|}
\hline & \multicolumn{2}{|c|}{ Location } \\
\hline & International & National \\
\hline 2016 Total Registered \% & $4 \%$ & $96 \%$ \\
\hline 2016 Total Completed \% & $6 \%$ & $94 \%$ \\
\hline 2017 Total Registered \% & $10 \%$ & $90 \%$ \\
\hline 2017 Total Completed \% & $3 \%$ & $97 \%$ \\
\hline 2018 Total Registered \% & $13 \%$ & $87 \%$ \\
\hline 2018 Total Completed \% & $5 \%$ & $95 \%$ \\
\hline
\end{tabular}

\begin{tabular}{|c|c|c|c|c|c|}
\hline & \multicolumn{5}{|c|}{ Education } \\
\hline & $\begin{array}{l}\text { Secondary } \\
\text { school }\end{array}$ & $\begin{array}{l}\text { Undergrad } \\
\text { cert/diploma }\end{array}$ & $\begin{array}{l}\text { Undergrad } \\
\text { degree }\end{array}$ & $\begin{array}{l}\text { Postgra } \\
\text { d }\end{array}$ & $\begin{array}{l}\mathrm{Ph} \\
\mathrm{D}\end{array}$ \\
\hline 2016 Total Registered \% & $6 \%$ & $10 \%$ & $31 \%$ & $50 \%$ & $3 \%$ \\
\hline 2016 Total Completed \% & $4 \%$ & $9 \%$ & $34 \%$ & $52 \%$ & $1 \%$ \\
\hline 2017 Total Registered \% & $5 \%$ & $10 \%$ & $33 \%$ & $50 \%$ & $2 \%$ \\
\hline 2017 Total Completed \% & $4 \%$ & $8 \%$ & $31 \%$ & $56 \%$ & $1 \%$ \\
\hline 2018 Total Registered \% & $6 \%$ & $10 \%$ & $34 \%$ & $48 \%$ & $2 \%$ \\
\hline 2018 Total Completed \% & $5 \%$ & $8 \%$ & $34 \%$ & $52 \%$ & $1 \%$ \\
\hline
\end{tabular}

